\title{
Automatyka pożarowa budynku w cyklu jego życia - metody weryfikacji działania, problemy z rozbudową systemów
}

\author{
Wojciech Węgrzyński, Piotr Antosiewicz, Grzegorz Krajewski
}

Fire Research Department, Building Research Institute (ITB), e-mail:w.wegrzynski@itb.pl,p.antosiewicz@itb.pl,g.krajewski@itb.pl

Streszczenie: W artykule przedstawiono problematykę wprowadzania do obrotu wyrobów budowlanych stanowiących elementy automatyki pożarowej. Problemy z wprowadzaniem do obrotu nowoczesnych rozwiązań zlokalizowano już w samym procesie badawczym oraz powolnej aktualizacji norm wyrobu. Także zastosowanie wyrobu w samym budynku przysparza trudności - autorzy przedstawiają zatem metodę gorącego dymu, pozwalającą na rzetelną i szybką ocenę tego współdziałania, także w trakcie użytkowania obiektu.

Słowa kluczowe: automatyka pożarowa, bezpieczeństwo pożarowe, KEM.

\section{Bezpieczeństwo pożarowe w obiekcie budowlanym}

Bezpieczeństwo pożarowe obiektu budowlanego to suma składowych związanych z możliwością powstania pożaru i jego rozprzestrzenienia się, zabezpieczeniami ograniczającymi jego oddziaływanie oraz skutkami tego oddziaływania na ludzi oraz konstrukcję. We wszystkich tych obszarach dysponujemy narzędziami, zarówno aktywnymi jak i pasywnymi, które zmieniają stan środowiska przyczyniając się do minimalizacji ryzyka związanego z pożarem. Urządzenia przeciwpożarowe, których działanie zależy od wykrycia pożaru i automatycznego przejścia w stan pracy w warunkach pożaru, często określa się wspólnym mianem automatyki pożarowej. Do rozwiązań tych zaliczamy przede wszystkim: systemy detekcji pożaru, stałe instalacje gaśnicze, systemy wentylacji pożarowej, dźwiękowe systemy ostrzegawcze, urządzenia odbiorcze alarmów przeciwpożarowych, przeciwpożarowe klapy odcinające, bramy pożarowe itp. Bez urządzeń automatyki pożarowej, obiekt oraz jego użytkownicy byliby bezbronni wobec zagrożenia pożarem. Ich wagę podkreślił także prawodawca, umieszczając wymagania w zakresie wykorzystania systemów automatyki pożarowej (SAP, SUG, DSO) w przepisach przeciwpożarowych [1] obowiązujących wszystkie obiekty budowlane - w odróżnieniu od przepisów technicznobudowlanych [2], które poza sytuacjami wyjątkowymi, dotyczą obiektów powstających lub przebudowywanych. Wymóg ten, choć zmieniany i aktualizowany, był zapisany już w wersji rozporządzenia obowiązującej od 1992 roku.

Pytanie stawiane przez autorów w niniejszej publikacji brzmi - czy powstające dzisiaj systemy automatyki pożarowej są w stanie działać skutecznie, w całym czasie życia obiektu budowlanego? Jeżeli nie, to jak długi okres życia tych wyrobów można przyjąć za realny oraz akceptowalny? 


\section{Stan prawny i ewolucja wymagań dla systemów bezpieczeństwa pożarowego}

Zakres urządzeń przeciwpożarowych objętych normalizacją ujęto w Mandacie 109 [4]. Wymagania szczegółowe dla urządzeń bezpieczeństwa pożarowego opisywane są w normach wyrobu, w wielu przypadkach objętych harmonizacją. W tym miejscu warto zwrócić uwagę na coraz bardziej ciążący problem długotrwałego procesu aktualizacji niektórych standardów, który zupełnie nie odzwierciedla pędzącego postępu w dziedzinie automatyki pożarowej. Paradoksalnie zatem, w obszarach nie objętych normami zharmonizowanymi - w szczególności w obszarze integracji urządzeń oraz sterowania urządzeniami wentylacji pożarowej, postęp jest znacznie szybszy, gdyż determinują go producenci oraz dokumenty krajowe (aprobaty techniczne).

Tabela 1 . Wybrane normy wyrobu wraz z podanym rokiem wydania

\begin{tabular}{llll}
\hline Wyrób & $\begin{array}{l}\text { Numer normy } \\
\text { PN-EN }\end{array}$ & Rok wydania & $\begin{array}{l}\text { Czy norma jest zhar- } \\
\text { monizowana? }\end{array}$ \\
\hline Centrale sygnalizacji pożarowej & $54-2$ & $2002+\mathrm{A} 1: 2007$ & Tak \\
\hline $\begin{array}{l}\text { Centrala dźwiękowego systemu } \\
\text { ostrzegawczego }\end{array}$ & $54-16$ & 2011 & Tak \\
\hline $\begin{array}{l}\text { Urządzenia i systemy transmisji } \\
\text { alarmu (UTA) }\end{array}$ & $54-21$ & 2009 & Tak \\
\hline $\begin{array}{l}\text { Centrale sterujące wentylacji poża- } \\
\text { rowej }\end{array}$ & $\begin{array}{l}\text { Ocena w systemie krajowym jako centrala sterująca urządzeniami } \\
\text { przeciwpożarowymi }\end{array}$ & $\begin{array}{l}\text { 2001 + A1:2004 } \\
+ \text { A2:2007 }\end{array}$ & Tak \\
\hline Zasilacz (SAP) & $54-4$ & 2007 & Tak \\
\hline Zasilacz (wentylacja pożarowa) & 12101-10 & 2007 & Tak \\
\hline Urządzenia wejścia-wyjścia & 54-18 & $\begin{array}{l}\text { Norma zharmonizowana (12101-6) jest niewystarczająca do prawi- } \\
\text { dłowej oceny urządzenia, ocena na podstawie procedur badaw- } \\
\text { czych w systemie krajowym }\end{array}$ \\
\hline Zestawy do różnicowania ciśnienia & & & \\
\hline
\end{tabular}

Wybrane normy wyrobów opisujące wymagania dla wybranych urządzeń bezpieczeństwa pożarowego przedstawiono w Tabeli 1 . Normy te zawierają ogólne wymagania stawiane urządzeniom bezpieczeństwa pożarowego, wraz z opisem procesu badawczego, zawierają też odniesienia do norm badawczych opisujących szczegóły badań, często jednak archaicznych i nieaktualnych.

\section{Ewolucja aktywnych systemów bezpieczeństwa pożarowego}

Rozwój systemów bezpieczeństwa pożarowego obserwujemy na co dzień, zarówno w naszej praktyce laboratoryjnej jak i działalności eksperckiej. Autorom publikacji, najbliższy jest obszar związany z wentylacją pożarową, a zatem kierunki rozwoju ogółu automatyki pożarowej zostaną przedstawione na tym przykładzie.

W obszarze wentylacji oddymiającej dróg ewakuacji, w przeszłości podstawowymi wykorzystywanymi rozwiązaniami były systemy grawitacyjne oparte o wyzwalacze termiczne lub lokalne systemy sterujące. W budynkach, w których wentylacja grawitacyjna nie spełniała oczekiwań projektantów lub z powodów technicznych wykonanie systemu grawitacyjnego nie było możliwe, wykorzystywano mieszane systemy wentylacji oddymia- 
jącej grawitacyjnej/mechanicznej w różnych konfiguracjach, wymagające już integracji $\mathrm{z}$ automatyką pożarową obiektu. Prawidłowe działanie tego typu rozwiązań wymagało sterowania i monitorowania pracy tylko kilku urządzeń. Rozwiązania obejmujące zabezpieczenie nie tylko dróg ewakuacji, ale i całych stref budynku (nazywanych strefami dymowymi) wymagają współpracy wielu urządzeń - wentylatorów, klap dymowych, klap odcinających itp. Każdy z tych elementów wymaga monitorowania oraz nadzoru - ważne jest nie tylko prawidłowe uruchomienie każdego składnika systemu, ale także kolejność w jakiej to uruchomienie następuje. Najbardziej skomplikowanymi systemami są systemy wentylacji pożarowej z wykorzystaniem wentylatorów strumieniowych, w których często wykorzystywane są skomplikowane scenariusze uruchamiania poszczególnych urządzeń, a centrale sterownicze poza pracą w trybie pożarowym, na co dzień służą wentylacji spalin. Rozwój obejmował także systemy napowietrzania dróg ewakuacji. Jako pierwsze popularność zyskiwały proste układy nawiewne oparte na wentylatorze i klapie, których celem było uzyskanie odpowiedniej wartości nadciśnienia w przestrzeni chronionej (np. klatce schodowej) i regulację jego wartości poprzez upust nadmiaru powietrza. Dzisiejsze systemy są znacznie bardziej zaawansowane technicznie, ich praca obejmuje dynamiczne monitorowanie warunków środowiska w obiekcie (ciśnienie, temperatura) jak i na zewnątrz (warunki pogodowe, kierunek wiatru), a praca urządzeń dostosowywana jest tak, aby najlepiej wypełnić oczekiwany cel działania. Dla tak skomplikowanych systemów niezbędne było stworzenie zupełnie nowej metody badawczej - co w tej chwili zawarto w projekcie nowej normy prEN 12101-6. Problemem niestety jest to, że choć norma nie weszła jeszcze w życie, opisana w niej procedura nie wystarcza dla wielu innowacyjnych rozwiązań już dzisiaj proponowanych przez producentów! Odpowiedzią na te problemy, jest powstawanie stanowisk pozwalających na łatwą rozbudowę czy mobilnych systemów pomiarowych jednak nie można tu mówić o literalnym wypełnieniu zapisów normy zharmonizowanej, dla bardziej skomplikowanych rozwiązań znów będzie istniała potrzeba prowadzenia równoległej certyfikacji w systemie krajowym.

\section{Skutki innowacji dla rozbudowy istniejących systemów}

Niestety, postęp technologiczny poza aspektem pozytywnym w postaci znaczącego podniesienia bezpieczeństwa pożarowego obiektów nowopowstających, niesie także problemy i komplikacje związane z niekompatybilnością rozwiązań technicznych i metod projektowania pomiędzy epokami. Często postęp nie oznacza poprawy - producenci dążą do optymalizacji swoich urządzeń, zastępując dotychczasowe sprawdzone komponenty tańszymi zamiennikami, bez pełnego określenia wpływu tych zmian na działanie urządzeń. Nasze doświadczenia pokazują, że nawet wymiana pozornie nieistotnego elementu (np. kondensatora, filtru przeciwzakłóceniowego itp.) może spowodować duże problemy w poprawnym funkcjonowaniu obciążonego systemu i jego wzajemną kompatybilnością [5].

Problemy funkcjonalne, które obserwujemy przy rozbudowie systemów dotyczą przede wszystkim ,pojemności” central sterujących. Istniejące urządzenia często nie posiadają możliwości dodania kolejnych punktów wejścia-wyjścia, a jedynym rozwiązaniem jest budowa drugiego równoległego systemu SAP. Rozwiązaniem tego problemu oferowanym dziś są interfejsy cyfrowe, te jednak w niedalekiej przyszłości mogą przysporzyć nam jeszcze więcej problemów ze wsteczną kompatybilnością niż dzisiejsze „,powolne” rozwiązania przekaźnikowe. Wiele funkcji systemów SAP związanych z realizacją zadań zapisanych w scenariuszu pożarowym realizowana jest przez inne systemy, np. urządzenia integrujące. Problemem w tym wypadku mogą być interfejsy użytkownika i platformy informatyczne, w oparciu, o które projektuje się urządzenie. Pytanie, czy za 10 lat systemy te będą tak 
samo sprawne jak dzisiaj? Czy postęp w informatyzacji rozwiązań nie spowoduje wycofania niektórych wykorzystywanych dziś protokołów? Warto spojrzeć wstecz, w ostatnich 15 latach mieliśmy 6 różnych wersji najpopularniejszego systemu operacyjnego Windows (2000, Me, XP, Vista, 7, 8, 10), większość z nich nie jest już wspierana przez producenta. Rozwiązania informatyczne $\mathrm{w}$ ochronie przeciwpożarowej często bazują na tych podstawowych „cywilnych” systemach operacyjnych - pytanie brzmi, jak będzie wyglądać ich działanie po zakończeniu wsparcia przez producenta systemu?

W niedalekiej przyszłości możemy spodziewać się jeszcze dalej idącej automatyzacji i „usamodzielniania się” komponentów systemów bezpieczeństwa pożarowego. Dostępne dzisiaj mikrokomputery typu Raspberry Pi czy Arduino dają nieograniczoną możliwość kreacji dowolnych układów pomiarowych i wykonawczych. Jeżeli dziś nie opracujemy odpowiednich metod kontroli i badań tego typu rozwiązań - można spodziewać się, że w niedalekiej przyszłości rynek zostanie zapełniony tanimi komponentami, których skuteczność jest nieznana. Przykładem innego palącego problemu, z którym będziemy musieli się zmierzyć są interfejsy i systemy wymiany danych oparte na transmisji danych przez światłowody czy transmisji bezprzewodowej - dzisiaj praktycznie niemożliwe do zbadania przy istniejących procedurach badawczych kompatybilności elektromagnetycznej.

\section{Metody oceny współpracy automatyki pożarowej}

Urządzenie przeciwpożarowe wprowadzone do obrotu zgodnie z prawem nie gwarantuje skutecznego działania - ważne jest powiązanie funkcjonalne wszystkich elementów automatyki pożarowej w jeden, współdziałający organizm. Do oceny tego współdziałania w Instytucie Techniki Budowlanej wykorzystujemy metodę gorącego dymu. Metoda ta polega na generacji strumienia gorącego powietrza, zmieszanego ze sztucznym dymem w badanej przestrzeni i obserwacji reakcji automatyki pożarowej obiektu na tak wywołany sztuczny pożar. Zestaw urządzeń do prowadzenia prób składa się z zestawu tac grzewczych $\mathrm{z}$ ciekłym paliwem, generatorów gorącego dymu odpornego na temperatury do $200^{\circ} \mathrm{C}$ oraz opcjonalnie urządzenia kontrolującego przebieg testu i integrującego wykorzystywane generatory dymu. Ilość tac z paliwem oraz liczba generatorów dymu dobierana jest indywidualnie dla każdego obiektu. Maksymalna moc pożaru testowego wykorzystywanego $\mathrm{w}$ trakcie testów z gorącym dymem wynosi do $1 \mathrm{MW}$. Generowany dym jest nietoksyczny i niebrudzący, a same próby mogą być prowadzone w czasie w którym obiekt jest wyłączony z normalnego użytkowania (noc, weekendy).

W zakresie oceny skuteczności działania systemu sygnalizacji pożaru i realizowanych sterowań w trakcie próby z gorącym dymem prowadzone są obserwacje działania poszczególnych elementów systemu oraz pomiar czasu po jakim to zadziałanie nastąpiło. Ważnym jest, aby kolejność uruchamiania się urządzeń była zachowana, gdyż w przeciwnym wypadku istnieje duże ryzyko poważnej awarii np. klap pożarowych lub wentylatorów wyciągowych.

Próby z gorącym dymem stanowią doskonałe narzędzie służące weryfikacji skuteczności działania systemów bezpieczeństwa pożarowego w obiektach budowlanych, ze szczególnym uwzględnieniem systemów wentylacji pożarowej. Z uwagi na ogrom obiektów jak i poziom ich skomplikowania i złożoności pod względem zastosowanych systemów, próby z gorącym dymem są właściwie jedynym narzędziem pozwalającym na ich skuteczną kontrolę w tak szerokim zakresie, w tak krótkim czasie. Prowadzenie prób cyklicznie w czasie eksploatacji obiektu pozwala na potwierdzenie gotowości systemów do zadziałania w czasie rzeczywistego pożaru, oraz pozwala wykryć i wyeliminować problemy powstałe w obszarze automatyki pożarowej budynku w trakcie codziennego użytkowa- 
nia. Jest to również doskonała okazja dla przeszkolenia personelu obsługującego system w warunkach zbliżonych, do rzeczywistego pożaru. Niestety wymóg okresowego przeprowadzania takich prób nie jest w chwili obecnej obligatoryjnie wymagany przez istniejące przepisy techniczno-budowalne i ppoż.

\section{Podsumowanie}

Obserwując ostatnich 20 lat rozwoju elektroniki użytkowej oraz automatyki pożarowej, można stwierdzić, że systemy instalowane dziś w budynkach będą w stanie pełnić swoją funkcję do czasu ,pierwszej dużej ingerencji w system” lub przez około 10 do 15 lat. Po tym czasie, urządzenia przestaną być kompatybilne z kolejnymi generacjami, lub utracą wsparcie producentów (także producentów podzespołów). Możliwość ich utrzymania będzie zależna od dostępności części zamiennych - już dzisiaj niektóre obiekty są „,zakładnikiem" zasobów magazynów elementów które wyszły z produkcji wiele lat temu. W miarę starzenia się systemów, możemy spodziewać się postępującego braku spełnienia najnowszych wymagań norm (o ile takie się ukażą) oraz coraz większych trudności z rozbudową urządzeń.

Także w samych obiektach budowlanych nadzór nad automatyką jest trudny. Do rzadkości należy widok samozamykacza w drzwiach, będącego w stanie pracy. Podobnie, często mamy do czynienia z niekompetentną obsługą systemów SAP czy urządzeń integrujących - prowadzi to do notorycznego „kasowania” wszystkich alarmów pożarowych i braku poprawnego nadzoru nad systemami bezpieczeństwa w obiekcie.

Należy pamiętać, że nawet odpowiednio zaprojektowany i wykonany system nie zadziała poprawnie, gdy będzie eksploatowany w nieprawidłowy sposób, bez odpowiedniej i wymaganej zazwyczaj przepisami prawa konserwacji oraz bez odpowiedniego poziomu wyszkolenia jego obsługi. Postęp w automatyzacji i cyfryzacji towarzyszących nam urządzeń jest nieuchronny, a często wręcz bardzo pożądany. Rozwój najnowszych technologii powoduje, że również bezpieczeństwo pożarowe to dziedzina nauki wymagająca dalszych badań i wniosków na przyszłość. Należy jednak dążyć do tego, aby obowiązujące przepisy, normy i kryteria oceny nie odbiegały znacząco od tempa tego postępu, niejednokrotnie uniemożliwiając wykorzystanie ,najnowszych technologii” z powodu braku odpowiedniego ,paragrafu”.

\section{Literatura}

1. Rozporządzenie Ministra Spraw Wewnętrznych i Administracji z dnia 7 czerwca 2010 r. w sprawie ochrony przeciwpożarowej budynków, innych obiektów budowlanych i terenów (Dz. U. nr 109, poz. 719), z późniejszymi zmianami.

2. Rozporządzenie Ministra Infrastruktury w sprawie warunków technicznych, jakim powinny odpowiadać budynki i ich usytuowanie z dnia 12 kwietnia 2002 r. (Dz.U. Nr 75, poz. 690), z późniejszymi zmianami.

3. Rozporządzenie Ministra Spraw Wewnętrznych i Administracji z dnia 16 czerwca 2003 r. w sprawie uzgadniania projektu budowlanego pod względem ochrony przeciwpożarowej(Dz.U. 2003 nr 121 poz. 1137).

4. Mandat Komisji Europejskiej nr 109, Wyroby służące do wykrywania i sygnalizacji pożaru, stałe urządzenia gaśnicze i ich podzespoły, wyroby służące do kontroli rozprzestrzeniania ognia i dymu oraz tłumienia wybuchu.

5. Antosiewicz P., Sulik P., Węgrzyński W. Kompatybilność elektromagnetyczna w urządzeniach przeciwpożarowych. Materiały budowlane 7 (2015) 49-51. 


\title{
Fire automation in the life cycle of a building - methods of verification, issues with system upgrade
}

\section{Wojciech Węgrzyński, Piotr Antosiewicz, Grzegorz Krajewski}

Fire Research Department, Building Research Institute (ITB),

e-mail:w.wegrzynski@itb.pl,p.antosiewicz@itb.pl,g.krajewski@itb.pl

\begin{abstract}
This article presents the issues with the marketing of construction products that are part of fire automation of a building. The issues in marketing of the newest solutions are localised already within the testing process and the slow process of updating current standards. Also mounting the construction product bring new challenges - authors present a method of hot smoke testing, that allows for a quick and reliable assesment of system cooperation, also in the life of the building.
\end{abstract}

Keywords: fire automation, fire safety, EMC. 